\title{
Comparative Analysis on Multiple Criteria Decision Making Techniques: An Application
}

\author{
Duygu Usta (Corresponding author) \\ Department of Econometrics, Faculty of Economics, \\ Marmara University, Istanbul, Turkey \\ E-mail: duygu.usta@marmara.edu.tr \\ ORCID: 0000-0002-7113-4570 \\ Ali Hakan Buyuklu \\ Department of Statistics, Faculty of Arts\&Science, \\ Yildiz Technical University, Istanbul, Turkey
}

\begin{abstract}
Multi-Criteria Decision Making (MCDM) Problems are used for solving complex problems with quantitative and qualitative criteria. These methods include decision, modeling and analysis process. Decision making activity is the process of determining the optimal decision among the alternatives under the condition of meeting the intended criteria. MCDM has a wide range of application areas. It may be used in problem solving in career planning, personal decision at micro scale, investment decisions at enterprises or strategic decisions at medium scale, and making economic decisions at macro scale. Many studies may be found in literature in which MCDM methods are used. The aim of this study is application and comparison of three MCDM methods such as AHP, ELECTRE and TOPSIS on career planning. The study first gives theoretical information about the three widely used MCDM methods, Analytic Hierarchy Process (AHP), ELECTRE and TOPSIS and then compares the results from the three analysis types in order to find the optimal decision by means of an application.
\end{abstract}

Keywords: Multi Critera Decision Making, Career Planning, AHP, ELECTRE, TOPSIS

DOI: $10.7176 / J S T R / 5-11-07$

\section{Çok Kriterli Karar Verme Yöntemleri Üzerine Karşılaștırmalı Analiz: Bir Uygulama}

\begin{abstract}
Özet
Nicel ve nitel kriterlere sahip karmaşık problemleri çözmek için Çok Kriterli Karar Verme Yöntemleri kullanılır. Bu yöntemler karar süreci, kriterlere göre modelleme ve analiz etme sürecini kapsar. Karar verme işlemi, istenilen kriterlerin sağlanması şartı altında alternatifler içerisinde optimal kararın belirlenmesi sürecidir. Çok Kriterli Karar Verme Yöntemlerinin uygulama alanı oldukça geniştir. Mikro ölçekte kariyer planlaması, kişisel kararlar, orta ölçekte, işletmelerde yatırım kararları, stratejik kararlar makro ölçekte ise makro ekonomik kararların verilmesi gibi problemlerin çözümünde kullanılırlar. Literatürde Çok Kriterli Karar Verme Yöntemlerinin kullanıldı̆̆ı birçok çalışma yer almaktadır. Bu çalışmada kariyer planlaması amaçlanmıştır. Çalışmada, en çok kullanılan Çok Kriterli Karar Verme Yöntemlerinden olan Analitik Hiyerarşi Prosesi (AHP), ELECTRE ve TOPSIS yöntemleri hakkında teorik bilgi verildikten sonra istatistik bölümünden yeni mezun olmuş bir kişi için iş alternatiflerinden en uygununu seçme problemi çözülmüştür. Böylelikle her üç analiz türü içinde optimal karar bulunup sonuçlar karşılaştırılmıştır.
\end{abstract}

Anahtar Kelimeler: Çok Kriterli Karar Verme, Kariyer Planlama, AHP, ELECTRE, TOPSIS

\section{Giriş}

Karar verme, günlük hayatın her alanında karşı karşıya kalınan bir durumdur. Kişiler, gruplar veya kurumlar birçok konu karşısında bir veya birden fazla kriteri göz önüne alarak karar vermek durumunda 
kalmaktadırlar. Tek kriter olduğu durumda karar vermek kolay olmakta fakat nicel ve nitel birden fazla kriter ve bu kriterlerin de alt kriterleri göz önüne alındığında karar verme süreci zorlaşmaktadır. Aynı zamanda karar vericilerin kriterlere verdikleri önem derecelerinin farklı olması da bu süreci zorlaştıracaktır. Bu tip problemlerin çözümü için Çok Kriterli Karar Verme Yöntemleri geliştirilmiştir. ÇKKV yöntemlerinin birçok çeşidi vardır. Çalışmada bu yöntemlerden Analitik Hiyerarşi Prosesi (AHP), ELECTRE I ve TOPSIS yöntemleri üzerinde durulmuştur. Bu yöntemler birçok alanda kullanılmaktadır. Fakat literatürde bu üç yöntemin kariyer planlaması problemi üzerinde uygulanarak sonuçların karşılaştırıldığı bir çalışmaya rastlanmamıştır.

Lisans eğitiminin bitmesiyle, birçok iş alanına sahip bir bölüm bitirmiş mezunların çoğu hangi alana yönelecekleri ve hangi sektörü seçecekleri konusunda kararsız kalmaktadırlar. Seçenek fazla olunca kişiler kendi kriterlerine göre önlerine çıkan alternatiflerden en iyisini seçmeye çalışırlar. Çalışmada istatistik bölümünden mezun olmuş bir kişi için uygun iş alternatifi seçimi gerçekleştirilmiştir.

\section{Kariyer Planlaması}

Kariyer, iş hayatında belirlenen hedeflerin tamamıdır. Kişinin yaptığ eğitimler, tecrübeler ve mesleki olarak gelişme sürecinin tamamıdır. Kariyerin bir sonu yoktur. İş hayatı boyunca yapılanlar ve planlananlar bu sürece dahildir. Kişinin kariyeri hem kendi için hem de çalıştığ kurum için oldukça önemlidir. Kişinin toplumdaki durumunu belirlemesine ve kişiliğinin gelişmesine yardımcı olur. Kişinin ihtiyacı olan maddi gücü sağlamanın yanı sıra psikolojik olarak iş tatmini sağlar. Çalıştığı yerden ve şartlardan tatmin olan kişi kariyerinde daha iyi yerlere gelmek için motivasyonu ve performansını arttırarak kuruma da daha faydalı olur. Böylelikle başarılı kişiler ile başarılı kurumlar ortaya çıkar.Lisans eğitiminin bitmesiyle, birçok iş alanına sahip bir bölüm bitirmiş mezunların çoğu hangi alana yönelecekleri ve hangi sektörü seçecekleri konusunda kararsız kalmaktadırlar. Seçenek fazla olunca kişiler kendi kriterlerine göre önlerine çıkan alternatiflerden en iyisini seçmeye çalışırlar. İstatistik bölümü çok geniş bir iş alanına sahiptir. $\mathrm{Bu}$ iş alanlarının birkaçının şartlarını sağlayan mezun, bu alanlardan hangisini seçeceğine karar verirken güçlük çekebilmektedir. Çünkü seçeceği alternatif mezunun kariyerini etkileyecektir. Kariyer kişi için bu kadar önemliyken kişi önüne çıkan iş alternatiflerinden kendisi için en uygununu seçmek istediğinde birçok kriter devreye girdiği zaman çıkmaza düşebilir. Bu kriterler farklı kişiler için farklı olsa da kariyer seçimi yaparken maaş, sosyal haklar gibi herkes tarafından dikkate alınan kriterler de mevcuttur. Bu kriterlerin belirlenmesi ve birden çok kriterin göz önüne alınarak en uygun seçimin yapılması için çok kriterli karar verme yöntemleri kullanılır.

\section{Literatür Özeti}

AHP yöntemi 1970'li yıllarda Thomas L. Saaty tarafından geliştirilmiştir. Saaty, AHP ve özvektör üzerinde durmuş, AHP' ye ilişkin bazı matematiksel kavramlardan bahsetmiştir (Saaty, 1990). Kuruüzüm ve Atsan, AHP yönteminin işletmecilik alanında uygulamalarını yapmıştır (Kuruüzüm ve Atsan, 2001). Yaralıŏlu, AHP'yi performans değerlendirmede kullanmıştır (Yaralığlu, 2001). Dağdeviren ve Eren, tedarikçi firma seçiminde AHP yöntemini kullanmıştır (Dağdeviren ve Eren, 2001). Ramanathen ve Ganesh, çok kriterli kaynak dağıtım problemlerinin çözümünde AHP'yi kullanmışlardır (Ramanathen ve Ganesh, 1995). Yoo ve Choi, havaalanında yolcu kontrollerinde güvenlik önlemlerini geliştirmede AHP'yi kullanmışlardır (Yoo ve Choi, 2006). An, Kim ve Kang, üç farklı modelin doğruluğunu karşılaştırmış bunun sonucunda AHP modelinin diğerlerine göre daha doğru ve güvenilir olduğunu ortaya koymuşlardır. AHP yardımıyla inşaat fiyatlarının tahmin edilmesi konusunu işlemişlerdir (An vd., 2007). Dağdeviren, Akay ve Kurt, iş değerlendirme sistemi tasarlamışlar ve bunu bir elektrik işletmesinde farklı işlerin değerlendirilmesinde kullanmışlardır (Dağdeviren vd., 2004). Erpolat ve Cinemre iş sektörü seçiminde AHP yöntemini kullanmışlardır. (Erpolat ve Cinemre, 2006).

ELECTRE yöntemi, 1966 yılında Bernard Roy tarafından geliştirilmiştir. Roy, ELECTRE yöntemlerinin teoremlerini açıklamıştır (Roy, 1991). Soner ve Önüt, havalandırma ve klima üreten bir firmanın, belirli bir ürünü için kullanacağı tedarikçilerine ilişkin verileri kullanarak tedarikçi seçiminde ELECTRE ve AHP yöntemlerini uygulamışlardır (Soner ve Onüt, 2006). Yürekli, taarruz helikopterleri seçiminde ELECTRE yöntemini uygulamıştır (Yürekli, 2008).

TOPSIS yöntemi 1981 y1lında Hwang ve Yoon tarafindan ELECTRE yönteminin temelleri üzerinde geliştirilmiştir. Dumanoğlu, İMKB'de işlem gören çimento şirketlerinin mali performansını TOPSIS yöntemiyle değerlendirmiştir (Dumanoğlu, 2010). Alp ve Engin, trafik kazalarının nedenleri ve sonuçları arasındaki ilişkinin TOPSIS ve AHP yöntemlerini kullanarak analiz etmiştir (Alp ve Engin, 2011). Yurdakul ve İç, Türk otomotiv firmalarının performans ölçümünde TOPSIS yöntemi kullanmıştır (Yurdakul ve İç, 2003). 


\section{4. Çok Kriterli Karar Verme}

Kişilerin günlük yaşamlarında karşılarına çıkan karar verme sorunları, genellikle ikiden fazla ve birbiriyle çelişen karmaşık kriterlere sahiptir. Kriter sayısı arttıkça kişilerin karar vermesi için yapılan işlemler çoğalmakta dolayısıyla karar verme zorlaşmaktadır. ÇKKV, karar vericinin sayılabilir sonlu ve sayılamaz seçenekler arasından en az iki kriteri dikkate alarak seçim yapmasıdır. Karar birimlerinin bir alt dalı olan çok kriterli karar verme, karar sürecini kriterlere göre modeller ve analiz eder (Ersöz ve Kabak, 2010).

Tablo 4.1 Çok Kriterli Karar Verme Yöntemlerinin Sınıflandırılması

\begin{tabular}{|c|c|c|c|}
\hline & $\begin{array}{l}\text { Karar Vericiden } \\
\text { Gelen Bilgi }\end{array}$ & Bilginin Önem Durumu & Yöntemin Temel Sınıfı \\
\hline \multirow{6}{*}{$\begin{array}{l}\text { ÇOK } \\
\text { KRİTERLİ } \\
\text { KARAR } \\
\text { VERME }\end{array}$} & Bilgi Yok & & Dominant, Maxmin, Minmax \\
\hline & \multirow{4}{*}{$\begin{array}{l}\text { Niteliklere Ait } \\
\text { Bilgi }\end{array}$} & Standart Seviye & Birleşik, Birleşik Olmayan \\
\hline & & Ordinal & $\begin{array}{l}\text { Permütasyon ile, } \\
\text { Lexicographic, Eliminasyon }\end{array}$ \\
\hline & & Kardinal & $\begin{array}{l}\text { Doğrusal Atama, SAW } \\
\text { AHP, ELECTRE, TOPSIS }\end{array}$ \\
\hline & & İkamenin Marjinal Oranı & Hiyerarşik Değişim \\
\hline & $\begin{array}{l}\text { Alternatiflere Ait } \\
\text { Bilgi }\end{array}$ & Tercihler & $\begin{array}{l}\text { LINMAP } \\
\text { İnteraktif SAW }\end{array}$ \\
\hline
\end{tabular}

Kaynak: Evangelos Triantaphyllou "Multi-Criteria Decision Making Methods: Acomperative Study", Kluwer Academic Publishers, Dordrecht, 2000, Vol.3, s.13.

Bu yöntemlerde, birçok alternatif arasından sınırlı sayıda alternatif seçilir. Problemle ilgili kriterler belirlenir. Kriterler arasında farklı ölçüm birimine sahip olanlar varsa bu ölçüm farklılıklarının giderilmesi gerekir. Örneğin, nitel ve nicel kriterlerin ölçüm birimi farklıdır fakat AHP yönteminde bu farklılık 1-9 ölçeğiyle ortadan kaldırılmıştır. Genellikle bütün ÇKKV problemleri kriterlerin göreli önem ağırlıklarını bulabilmek için bilgiye ihtiyaç duymaktadır. Önem ağırlıklarını karar verici belirleyebilir veya bu ağırlıklar çeşitli yöntemler kullanılarak bulunabilir. ÇKKV yöntemleri hem niteliksel hem de niceliksel olarak daha iyi model senaryoları geliştirmektedir (Türkmen ve Çağıl, 2012). ÇKKV teknikleri birden çok ve birbiriyle çelişen kriterler olduğu durumda karar verme süreci için ortak bir platform yaratır. Çok büyük miktardaki veri setlerini değerlendirmeye alabilir. Nicel ve nitel kriterleri birlikte değerlendirebilir. Karar sürecini sistematik bir şekilde yürütür. Karmaşık konuların algılanmasını kolaylaştırır.

ÇKKV yöntemlerinde bazen alternatifler arasında karșılaştırılamama sorunu olabilir. Bir alternatif bir kritere göre diğer seçenekten üstünken başka bir kritere göre tam tersi bir durum söz konusu olduğu zaman hangi alternatifin daha iyi olduğunu belirleyebilmek için ek bilgi gerekmektedir. Bu nedenle sorunlar matematiksel olarak çok net tanımlanamaz. Net olarak tanımlanamadığı için, yalnızca uzlaşık çözümler elde edilebilir. En iyi uzlaşık çözümler özneldir, karar vericiye bağlıdır.

\section{Yöntemler}

\subsection{Analitik Hiyerarşi Prosesi}

Analitik Hiyerarşi Prosesi, ilk olarak Myers ve Alpert tarafından ortaya atılıı̣ ve 1977 yılında Profesör Thomas Lorie Saaty tarafindan birden çok kriter içeren karmaşık problemlerin çözümünde kullanılmak üzere modellenip geliştirilmiştir (Yaralığlu, 2001). En önemli özelliği alternatiflerin seçiminde nicel ve nitel kriterlerin birlikte kullanılmasını sağlamasıdır. Ayrıca gerçek yaşamda olduğu gibi grupça karar vermede görülen düşünce ayrılıklarını da dikkate alabilir (Dağdeviren vd., 2004). Karar vericinin, bir problemin çözüm yolları karşısındaki tercihleri genellikle yargılarına göre değişim gösterir. Bunun sonucu olarak insan yargısının karar verme sürecinde dikkate alınması karar vermedeki etkinliğini doğrudan etkileyebilir. Çünkü farklı bireylerin aynı karar problemlerine ait kriterleri farklı olabilir ve bu kriterlerin seçenekleri bile farklılık gösterebilir. Bu gibi durumlarda verilen kararın etkinliğini arttrrabilmek için kullanılan yöntemlerden biri de AHP yöntemidir. Yöntem çok geniş bir kullanım alanına sahiptir ve hemen hemen her alan için karar probleminde etkin olarak kullanılmaktadır (Kuruüzüm ve Atsan, 2001) AHP yönteminde herhangi bir karar alternatif probleme eklendiğinde veya çıkarıldığında karar alternatiflerinin sıralaması değişmektedir. AHP nasıl bir karar verilmesinden çok ne derece iyi bir karar verilmesiyle ilgilidir (Kuruüzüm ve Atsan, 2001).

AHP, grup halinde karar vermede görülen düşünce ayrıllklarını da dikkate alabilmektedir. Bu yüzden grup kararlarında kullanıma uygundur. Duyarlılık analizini etkin bir şekilde gerçekleştirebilmektedir. 
Karar vericinin yargılarının tutarlılığını ölçmesine imkân tanır. Böylelikle tutarsızlık durumunda, karar verici verdiği hükümleri tekrar düşünerek düzeltebilmektedir. AHP tam tutarlılık değil, yeterince tutarlilık ister (Saaty ve Vargas, 1987).

Yöntemde öncelikle amaç belirlenir, bu amacı etkileyen kriterler hesaplanır ve bu kriterler arasındaki ilişkileri temsil eden bir model oluşturulur. İlgili alt kriterler bölünüp düzenlenerek hiyerarşik yap1 oluşturulur. Bu yapıyı oluştururken duygu ve bilgileri yansıtan yargılara da yer verilir. Seviye sayısı probleme göre değişmektedir (Dağdeviren vd., 2004).

Tablo 5.1. Kriterlerin Hiyerarşik Yapısı

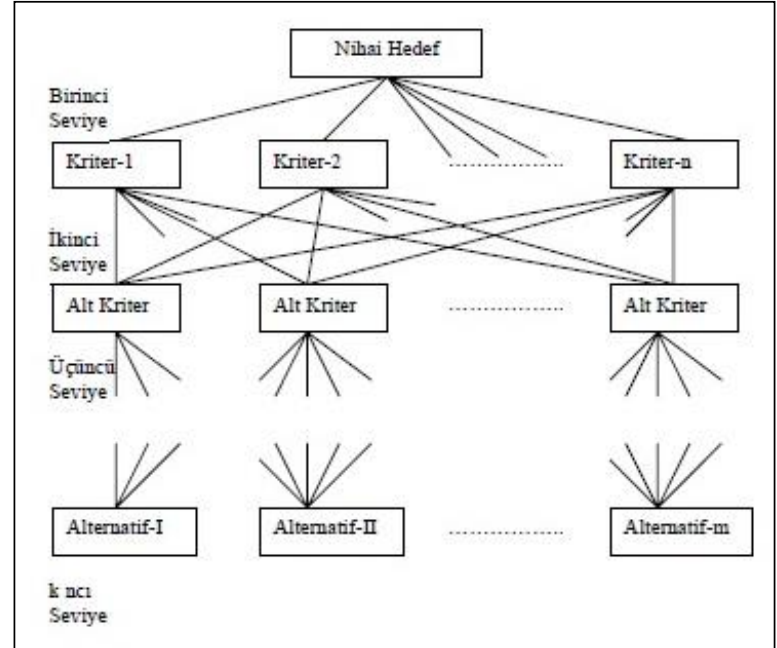

Kaynak: Fatemeh Zahedi, “The Analytical Hierarchy Process A Survey of the Method and its Applications”, Interfaces, 1986,

$$
\text { s.50-73. }
$$

Hiyerarşi yapısı oluşturulduktan sonra, karar verici tarafından karar seçeneklerinin değerlendirilecek kriterlere göre birbirleriyle ikili karşılaştırılma matrisleri oluşturulur. İkili karşılaştırmada hiyerarşideki elemanlar, bağlı oldukları bir üst kademedeki elemana göre göreli önemlerinin belirlenebilmesi için ikili olarak karşılaştırılır. Saaty, karar kriterlerinin ve alternatiflerinin ikili karşılaştırılması için sözel kıyaslamalar yapılan bir ölçek geliştirmiştir. Yapılan bu sözel kıyaslamalara 1-9 arasında sayısal değerler verilir (Saaty, 1980).

Tablo 5.2. AHP'de Kullanılan 1-9 Temel Ölçeği

\begin{tabular}{|c|c|c|}
\hline $\begin{array}{c}\text { Önem } \\
\text { Değerleri }\end{array}$ & TANIM & AÇIKLAMA \\
\hline $\mathbf{1}$ & Eşit önem & $\begin{array}{c}\text { İki faaliyetin birbirlerine } \\
\text { üstünlükleri yoktur. }\end{array}$ \\
\hline $\mathbf{3}$ & Zayıf derecede önem & $\begin{array}{c}\text { Bir faaliyet diğerine göre çok az } \\
\text { derecede tercih edilir. }\end{array}$ \\
\hline $\mathbf{5}$ & $\begin{array}{c}\text { Kuvvetli derecede } \\
\text { önem }\end{array}$ & $\begin{array}{c}\text { Bir faaliyet diğerine göre kuvvetli } \\
\text { derecede tercih edilir. }\end{array}$ \\
\hline $\mathbf{7}$ & $\begin{array}{c}\text { Çok kuvvetli derecede } \\
\text { önem }\end{array}$ & $\begin{array}{c}\text { Bir faaliyet diğerine göre güçlü } \\
\text { derecede tercih edilir. }\end{array}$ \\
\hline $\mathbf{9}$ & Aşırı derecede önem & $\begin{array}{c}\text { Bir faaliyetin diğerine göre } \\
\text { üstünlüğ̈ünün en yüksektir. }\end{array}$ \\
\hline $\mathbf{2 , 4 , 6 , 8}$ & Ara değerler & $\begin{array}{c}\text { Uzlaşma gerektĭğinde kullanılmak } \\
\text { üzere iki ardışı yarg1 arasındaki } \\
\text { değerlerdir. }\end{array}$ \\
\hline
\end{tabular}

kili karşılaştırmalar sonucunda elde edilen değerler AHP yönteminde ikili karşılaştırma matrisi adı verilen bir matrise dönüştürülür. Karşılaştırılacak $n$ tane kriter varsa $C(n, 2)=n(n-1) / 2$ adet karşılaştırma yapılır. $a_{i j}$ elemanı, i.kriter ile j. kriterin ikili karşılaştırma değerini göstermektedir. Aşağıda genel olarak ikili karşılaştırma matrisi gösterilmektedir (Saaty, 1990). 


$$
\left[\begin{array}{cccc}
a_{11} & a_{12} & \cdots & a_{1 n} \\
a_{21} & a_{22} & \cdots & a_{2 n} \\
\vdots & \vdots & \ddots & \vdots \\
a_{n 1} & a_{n 2} & \cdots & a_{n n}
\end{array}\right]_{n \times n}=\left[\begin{array}{cccc}
w_{1} / w_{1} & w_{1} / w_{2} & \cdots & w_{1} / w_{n} \\
w_{2} / w_{1} & w_{2} / w_{2} & \cdots & w_{2} / w_{n} \\
\vdots & \vdots & \ddots & \vdots \\
w_{n} / w_{1} & w_{n} / w_{2} & \cdots & w_{n} / w_{n}
\end{array}\right]_{n \times n}
$$

$\mathrm{Bu}$ ilişkiler matematiksel olarak aşağıdaki formül ile gösterilir.

$$
\frac{w_{i}}{w_{j}}=a_{i j} \quad(\mathrm{i}, \mathrm{j}=1,2,3, \ldots \ldots ., \mathrm{n})
$$

Burada $w_{i}$, i özelliğinin ağırlığını, $w_{j}$ ise $\mathrm{j}$ kriterinin ağırlı̆̆ını göstermektedir. İkili karşılaştırma karar matrisleri oluşturulduktan sonraki aşama öncelik vektörlerinin hesaplanmasıdır. Karşılaştırma matrislerinin özdeğer ve özvektörleri, öncelik sırasını belirlemeye yardımcı olur. En büyük özdeğere karşı1lk gelen özvektör öncelikleri belirler.

AHP yönteminde $\mathrm{W}$ öncelik vektörü aşağıda verilen eşitliğin çözülmesiyle bulunmaktadır (Dağdeviren $\mathrm{vd}, 2004)$.

$$
\left(A-\lambda_{\max } I\right) W=0
$$

Formülde verilen $\mathrm{A}$, ikili karşılaştırma matrisini, $\lambda_{\max }$, A matrisinin en büyük özdeğerini ve $\mathrm{W}$ ise bu özdeğere karşllık gelen özvektörü yani öncelik vektörünü ifade etmektedir.

Son aşamada duyarlılık analizi yapılır. Diğer bir deyişle alt öğelerde yapılan yargılarda değişiklik yapılarak verilen karar incelenir.

Karar vericinin kriterler arasında karşılaştırma yaparken tutarlı davranıp davranmadığını ölçmek için tutarll11k oranı hesaplanmaktadır. Tutarlılık oranı hesaplanırken tutarlılık indeksi (consistency index) ve rastgele indeks (random index) kullanılır. İkili karşılaștırma matrisinin en büyük özdeğerinin, $\mathrm{n}$ değerinden sapması tutarlılı̆̆ın ölçümü anlamına gelmektedir. Karşılaştırma matrisinin büyüklügüyle (n) bu ölçümün normalleştirilmesi Tutarlılık İndeksi (T.İ) olarak tanımlanmıştır. .Tutarlılık indeksi aşağıdaki formülle hesaplanır.

$$
T . \dot{I}=\frac{\lambda_{\max }-n}{n-1}
$$

Saaty ve arkadaşları, AHP yöntemi için tutarlılık oranını hesaplayabilmek için rastgele indeks serisi oluşturmuşlardır. Rastgelelik indeksleri ikili karşılaştırmalar matrislerinin tutarlılık indekslerinin ortalaması alınarak bulunmuştur. $1 \leq n \leq 15$ boyutlu matrisler için Saaty bu değerleri aşağıdaki gibi hesaplamıştır (Saaty, 1980).

Tablo 5.3. Rasgele İndeks Değerleri

\begin{tabular}{|c|c|c|c|c|c|c|c|c|c|c|c|c|c|c|c|}
\hline $\mathbf{n}$ & 1 & 2 & 3 & 4 & 5 & 6 & 7 & 8 & 9 & 10 & 11 & 12 & 13 & 14 & 15 \\
\hline R.í & 0 & 0 & 0,58 & 0,9 & 1,12 & 1,24 & 1,32 & 1,41 & 1,45 & 1,49 & 1,51 & 1,48 & 1,56 & 1,57 & 1,59 \\
\hline
\end{tabular}

Buna göre tutarlılık oranı, tutarlılık indeksinin aynı boyuttaki matrise karşılık gelen rastgelelik indeksine bölünmesiyle bulunur.

$$
\text { T.O. }=\frac{T . \dot{I}}{R . \dot{I}}
$$

Tutarlılık oranı değeri 0.10 'dan küçük çıkması, karşılaştırma matrisinin dolayısıyla yargıların yeterli derecede tutarlı olduğu ve çözüme ulaşmak için yöntemin uygulanmasına devam edilebileceğini göstermektedir (Yurdakul, 2002). 


\subsection{ELECTRE Yöntemi}

ELECTRE (Elemination et Choix Traduisant La Realite-Elimination and Choice Translating Reality) ilk olarak Benayoun, Roy ve arkadaşları tarafindan 1966 yılında ortaya atılıış, daha sonra Roy, Nijkamp ve Van delf tarafindan geliştirilerek bugünkü halini almıştır. Yöntem, her bir değerlendirme kriteri için alternatifler arasındaki ikili üstünlük kıyaslamalarına dayanır. Yapılan bu işleme sıralama işlemi denir. $\mathrm{Bu}$ sıralamaya göre alternatiflerin birbirine olan üstünlüğü veya tercih edilebilirliği incelenebilmektedir (Daşdemir ve Güngör, 2002).Yöntem, alternatiflerin aldıkları kriter değerlerine göre uyum ve uyumsuzluklarını ölçmektedir. ELECTRE yöntemi çok sayıda alternatifin ve az sayıda kriterin bulunduğu karar problemini çözmek için daha uygundur. Bu metot, az tercih edilecekleri eleyerek karar vericiye alternatifleri incelerken daha açık bir görüş kazandırır. ELECTRE yöntemini diğer karar verme yöntemlerinden ayıran bir özellik bu yöntemin temelde alternatife ait zayıf tarafların aynı alternatife ait güçlü taraflarla telafi edilmesine imkan vermeyen bir yöntem olmasıdır. İki alternatiften birinin diğerine üstün olması için bariz göstergelerin olması gerekmektedir (Triantaphyllou, 2000).

ELECTRE yönteminin aşamaları sırasıyla aşağıda verilmiştir (Yücel ve Ulutaş, 2009).

Karar matrisinin satırlarında üstünlükleri sıralanmak istenen karar alternatifleri (m) sütunlarında ise karar vermede kullanılacak kriterler (n) yer almaktadır. Aşağıda gösterilen A matrisi ELECTRE uygulaması için oluşturulan başlangıç matrisidir.

$A_{i j}=\left[\begin{array}{cccc}a_{11} & a_{12} & \cdots & a_{1 n} \\ a_{21} & a_{22} & \cdots & a_{2 n} \\ \vdots & \vdots & \ddots & \vdots \\ a_{m 1} & a_{m 2} & \cdots & a_{m n}\end{array}\right]$

Normalleştirilmiş, diğer bir deyişle standartlaştırılmış karar matrisinin elemanları A matrisinin elemanları kullanılarak aşağıdaki formül yardımıyla hesaplanır.

$x_{i j}=\frac{a_{i j}}{\sqrt{\sum_{k=1}^{m} a_{k j}^{2}}}$
$X_{i j}=\left[\begin{array}{cccc}x_{11} & x_{12} & \cdots & x_{1 n} \\ x_{21} & x_{22} & \cdots & x_{2 n} \\ \vdots & \vdots & \ddots & \vdots \\ x_{m 1} & x_{m 2} & \cdots & x_{m n}\end{array}\right]$

Karar vericiye göre değerlendirme kriterlerinin önemi farklı olabilir. Bu farklılıkları çözüme yansıtabilmek için ağırlıklı standart karar matrisi hesaplanır. Bu aşamada öncelikli olarak karar verici, değerlendirme kriterlerinin önem ağırlıkların $\left(w_{i}\right)$ belirlemelidir. Bundan sonra $\mathrm{X}$ matrisinin her bir sütunu, karar verici tarafindan belirlenen bu önem ağırlıkları ile çarpılarak Y matrisi oluşturulur. Y matrisi aşă̆ıdaki gibidir.

$Y_{i j}=\left[\begin{array}{cccc}w_{1} x_{11} & w_{2} x_{12} & \cdots & w_{n} x_{1 n} \\ w_{1} x_{21} & w_{2} x_{22} & \cdots & w_{n} x_{2 n} \\ \vdots & \vdots & \ddots & \vdots \\ w_{1} x_{m 1} & w_{2} x_{m 2} & \cdots & w_{n} x_{m n}\end{array}\right] \quad$ ve $\quad \sum_{i=1}^{n} w_{i}=1$

Sıradaki aşama uyumluluk ve uyumsuzluk setlerinin belirlenmesidir. Karar noktaları birbiriyle değerlendirme kriterleri açısından karşılaştırılır ve aşağıdaki formül yardımıyla setler belirlenir. Formülün temelinde satır elemanlarının birbirlerine göre büyüklüklerinin karşılaştırılması esası vardır.

$C_{k l}=\left\{\mathbf{j}, y_{k j} \geq y_{l j}\right\}, \mathrm{j}=1,2,3, \ldots \ldots . . \mathrm{n}$

Uyumluluk setindeki eleman sayısı, en fazla değerlendirme kriterinin sayısı (n) kadar olabilir. Ayrıca $\mathrm{k} \neq 1$ şartı bulunmaktadır. Örneğin $\mathrm{k}=2$ ve $\mathrm{l}=3$ için uyum seti $C_{23}$ ile gösterilir. Y matrisinin 2. ve 3 . satır 
elemanları karşı1ıklı olarak birbiriyle kıyaslanır. Eğer burada 4 değerlendirme kriteri varsa uyum seti en fazla 4 elemanlı olacaktır. Her uyumluluk setine $\left(C_{k l}\right)$ bir uyumsuzluk seti $\left(D_{k l}\right)$ karş̧lık gelir. Yani uyum seti sayısı kadar uyumsuzluk seti vardır. Bu kümenin elemanları uyum setinde olmayan j elemanlarından oluşur. Uyumsuzluk seti aşağıdaki formülle gösterilir.

$$
D_{k l}=\left\{\mathrm{j}, y_{k j}<y_{l j}\right\}, \quad \mathrm{j}=1,2,3, \ldots, \mathrm{n}
$$

Uyumluluk setleri oluşturulurken değerlendirme kriterlerine çok dikkat etmek gerekir. Çünkü kriterlere göre (5.5) deki eşitlik değişecektir. Örneğin, değerlendirme faktörü kar ise aynı formül kullanılacak fakat maliyet ise şart $y_{k j}<y_{l j}$ olacaktır.

$\mathrm{Bu}$ aşamadan sonra uyumluluk ve uyumsuzluk matrisleri oluşturulur. Uyumluluk matrisindeki elemanların değeri, uyumluluk indeksi aracılı̆̆ıla bulunur. Bu matrisler, köşegen üzerinde aynı karar noktalarını gösterdikleri için köşegenlerde değerleri yoktur. Uyumluluk indeksi $\left(C_{k l}\right)$ uyumluluk setinin içindeki kriter ile birleştirilmiş ağırlıkların toplamıdır. Dolayısıyla $\mathrm{C}$ matrisinin elemanları aşağıdaki formül yardımıyla hesaplanır.

$$
c_{k l}=\sum_{j \in C_{k l}} w_{j}
$$

Örneğin; $C_{12}=\{1,3\}$ ise uyumluluk matrisinin $c_{12}$ değeri $c_{12}=w_{1}+w_{3}$ olacaktır. Hesaplanan değerlerin yerine yazılmasıyla oluşan $\mathrm{C}$ matrisi aşağıda gösterilmiştir.

$$
C=\left[\begin{array}{cccc}
- & c_{12} & \cdots & c_{1 m} \\
c_{21} & - & \cdots & c_{2 m} \\
\vdots & \vdots & \ddots & \vdots \\
c_{m 1} & c_{m 2} & \cdots & -
\end{array}\right]
$$

Uyumsuzluk matrisi (D) belirli alternatifin rakip alternatiften düşüklük derecesini belirtmektedir. $\mathrm{Bu}$ matrisin elemanları aşağıdaki gibi tanımlanır.

$$
D_{k l}=\frac{\sum_{j}\left|Y_{k j^{*}}-Y_{l j^{*}}\right|}{\sum\left|Y_{k j}-Y_{l j}\right|}
$$

Uyumluluk matrisinde olduğu gibi uyumsuzluk matrisi de $\mathrm{m} \times \mathrm{m}$ boyutludur ve $\mathrm{k}=1$ için değer almamaktadır. Uyumsuzluk matrisi aşağıdaki gibi tanımlanır.

$$
D=\left[\begin{array}{cccc}
- & d_{12} & \cdots & d_{1 m} \\
d_{21} & - & \cdots & d_{2 m} \\
\vdots & \vdots & \ddots & \vdots \\
d_{m 1} & d_{m 2} & \cdots & -
\end{array}\right]
$$

Alternatiflerin birbirlerine olan üstünlüklerini görmek için üstünlük matrisleri oluşturulur. Uyumluluk Üstünlük Matrisi (F), uyumluluk eşik değerinin uyum matrisindeki elemanlarla karşılaştırılmasından elde edilir. Burada bahsedilen uyumluluk eşik değeri aşağıdaki formülle hesaplanır.

$$
\bar{c}=\frac{1}{m(m-1)} \sum_{k=1}^{m} \sum_{l=1}^{m} c_{k l} \quad, \quad k \neq l
$$

Uyumluluk eşik değeri $\frac{1}{m(m-1)}$ ile uyumluluk matrisinin elemanlarının toplamının çarpımına eşittir. Formüldeki m değeri karar noktası sayısını göstermektedir. Uyumluluk eşik değeri bulunduktan sonra, 
uyumluluk matrisindeki elemanlar bulunan bu eşik değeri ile karşılaştırılır. Eğer, karşılaştırılan uyumluluk matris elemanı eşik değeri geçerse ( $c_{k l} \geq \bar{c}$ olursa)

$a_{k}$ alternatifi $a_{l}$ alternatifinden bir ihtimal üstün olabilmektedir. $c_{k l}$ değeri büyüdükçe, k seçeneğinin 1 seçeneğine olan tercih edilirlik derecesi artmaktadır.

Uyumluluk üstünlük matrisinin (F) elemanları ise bu karşılaştırmalar sonucunda aşağıdaki gibi belirlenmektedir. eğer $c_{k l} \geq \bar{c}$ ise $f_{k l}=1$, eğer $c_{k l}<\bar{c}$ ise

$f_{k l}=0$ olur.

$F=\left[\begin{array}{cccc}- & f_{12} & \cdots & f_{1 m} \\ f_{21} & - & \cdots & f_{2 m} \\ \vdots & \vdots & \ddots & \vdots \\ f_{m 1} & f_{m 2} & \cdots & -\end{array}\right]_{m \times m}$

Uyumsuzluk üstünlük matrisi $(G)$ elemanları da uyumsuzluk eşik değerinin uyumsuzluk matrisinin elemanlarıyla karşılaştırılmasıyla oluşturulur. Uyumsuzluk eşik değeri $d$ aşağıdaki formül yardımıyla hesaplanir.

$$
\bar{d}=\frac{1}{m(m-1)} \sum_{k=1}^{m} \sum_{l=1}^{m} d_{k l}, \quad k \neq l
$$

Formüldeki m değeri karar noktası sayısını göstermektedir. Benzer şekilde uyumsuzluk üstünlük matrisi de uyumsuzluk matrisindeki elemanların $\frac{\bar{d}}{d}$ eşik değeri ile karşılaştırılması sonucunda aşağıdaki gibi belirlenmektedir. Eğer $d_{k l} \geq d$ ise $g_{k l}=0$, eğer $d_{k l}<d$ ise $g_{k l}=1$ olur.

$\mathrm{G}$ matrisi aşağıda gösterilmiştir.

$G=\left[\begin{array}{cccc}- & g_{12} & \cdots & g_{1 m} \\ g_{21} & - & \cdots & g_{2 m} \\ \vdots & \vdots & \ddots & \vdots \\ g_{m 1} & g_{m 2} & \cdots & -\end{array}\right]_{m \times m}$

Verilenlere göre, $c_{k l} \geq \bar{c}$ ve $d_{k l} \geq \bar{d}$ şartları oluşuyorsa k alternatifi 1 alternatifine tercih edilir. $\left(a_{k} \rightarrow a_{l}\right)$ şeklinde gösterilir.

Bu aşamadan sonra toplam üstünlük matrisi oluşturulur. Toplam üstünlük matrisinin elemanları aşağıdaki formülde gösterildiği gibi uyumluluk üstünlük ve uyumsuzluk üstünlük matrislerinin elemanlarının çarpılmasıla bulunur.

$$
e_{k l}=f_{k l} \times g_{k l}
$$

Toplam üstünlük matrisine bakılarak alternatiflerin tercih sırası çıkarılabilir. $e_{k l}=1$ olduğu durum, hem uyumluluk hem de uyumsuzluk kriteri kullanılarak $a_{k}$ alternatifinin, $a_{l}$ alternatifine göre mutlak üstün olduğu anlamına gelmektedir. Eğer toplam üstünlük matrisinin herhangi bir sütunun en az bir değeri 1' e eşitse, bu sütun ELECTRE yöntemi açısından uygun sıra aracilığıyla üstündür. Eğer bu aşamada üstünlükler net olarak anlaşılamıyorsa, net uyumluluk ve net uyumsuzluk indekslerinin hesaplanması gerekmektedir.

Net uyumluluk indeksi: $\quad c_{k}=\sum_{l=1}^{m} c_{k l}-\sum_{l=1}^{m} c_{l k} \quad, l \neq k$ 


$$
\text { Net Uyumsuzluk İndeksi: } \quad d_{k}=\sum_{l=1}^{m} d_{k l}-\sum_{l=1}^{m} d_{l k} \quad, l \neq k
$$

Hesaplanan değerlerden $c_{k}<0$ ve/veya $d_{k}>0$ değerini alan seçenek elenmelidir. $c_{k}$ 'lar büyükten küçüğe, $d_{k}$ 'lar küçükten

büyüğe sıralanır. Ve nihai sıralama elde edilmiş olur. $c_{k}$ değeri ne kadar büyük olursa ve $d_{k}$ değeri ne kadar küçük olursa

o seçeneğin tercih edilebilirlik derecesi artmaktadır (Triantaphyllou, 2000).

ELECTRE Yöntemi, kalitatif ve kantitatif verilerin karışık olarak değerlendirilmesini sağlayan kuvvetli bir yöntemdir. Diğer yöntemlerin aksine yüksek düzeyde kaynak gereksinimi yoktur. Birçok durumda baskın olmayan alternatifler alt kümesi verilebilir ve alternatiflerin kesin ve güçlü bir ön sıralamasını vermeyebilir fakat mevcut verilerin kalitesine göre alternatif seçim problemi için daha gerçekçi sonuçlar verebilir.

Yöntem bazen seçilen alternatifleri belirlemede yeterli değildir. Sadece lider alternatifler üretir. $\mathrm{Bu}$ yöntemde daha az elverişli olan alternatifler ortadan kaldırılarak problemin çözümü için daha açık bir görünüme sahip alternatifler seçilir. Bu yüzden birkaç kriterli ve çok alternatifli problemlerde kullanılması daha elverişli sonuçlar vermektedir (Roy, 1991).

\subsection{TOPSIS Yöntemi}

TOPSIS (Technique for Order Preference by Similarity to Ideal Solution) yöntemi Yoon ve Hwang tarafindan 1981 yılında ELECTRE yöntemine bir alternatif olarak ELECTRE yönteminin temelleri üzerine geliştirilmiş̧ir. Bu nedenle iki yönteminde ilk iki aşaması aynıdır. İki yöntemde de karar matrisi standartlaştırılarak başlanır ve ikinci aşamada kriterlerin ağırlık değerlerini karar vericiden alır. $\mathrm{Bu}$ aşamadan sonra yöntemler farklılaşır (Dumanoğlu, 2010). TOPSIS, ideal çözüme en yakın, negatif ideal çözüme en uzak alternatifin en iyi olduğunu gösterirken, ELECTRE, alternatiflerden birinin diğerine olan üstünlüğüne göre eleme yapar. TOPSIS yöntemi karar noktalarının ideal çözüme yakınlığı prensibine dayanır. Bu prensibe göre seçilmiş alternatif, ideal çözüme en yakın mesafede, negatif ideal çözüme ise en uzak mesafede yer almaktadır. Bulunan bu çözümlerle alternatiflerin sıralaması yapılmaktadır. Yöntemin aşamaları aşağıda verilmiştir (Jadidi vd., 2008). TOPSIS yönteminin ilk iki aşaması ELECTRE yöntemiyle aynıdır dolayısıyla standartlaştırılmış karar matrisi, A matrisinin elemanlarından yararlanılarak aşağıdaki gibi hesaplanır. Hesaplamalar sonucu R matrisi aşağıdaki gibi elde edilir.

$r_{i j}=\frac{a_{i j}}{\sqrt{\sum_{k=1}^{m} a_{k j}^{2}}}$ formülünden,

$R_{i j}=\left[\begin{array}{cccc}r_{11} & r_{12} & \ldots & r_{1 n} \\ r_{21} & r_{22} & \ldots & r_{2 n} \\ \cdot & & & \cdot \\ \cdot & & & \cdot \\ \cdot & & & \cdot \\ r_{m 1} & r_{m 2} & \ldots & r_{m n}\end{array}\right]$

Karar vericiye göre değerlendirme kriterlerinin önemi farklı olabilir. $\mathrm{Bu}$ farklılıkları çözüme yansıtabilmek için ağırlıklı standart karar matrisi hesaplanır. Bu aşamada öncelikli olarak karar verici değerlendirme kriterlerinin önem ağırlıkların $\left(w_{i}\right)$ belirlemelidir. Bundan sonra $\mathrm{R}$ matrisinin her bir sütunu, karar verici tarafindan belirlenen bu önem ağırlıkları ile çarpılarak V matrisi oluşturulur. 
$V_{i j}=\left[\begin{array}{cccc}w_{1} r_{11} & w_{2} r_{12} & \ldots & w_{n} r_{1 n} \\ w_{1} r_{21} & w_{2} r_{22} & \ldots & w_{n} r_{2 n} \\ \cdot & & & \cdot \\ \cdot & & & \cdot \\ \cdot & & & \cdot \\ w_{1} r_{m 1} & w_{2} r_{m 2} & \ldots & w_{n} r_{m n}\end{array}\right]$ ve $\sum_{i=1}^{n} w_{i}=1$

Yöntem, her bir değerlendirme kriterinin monoton artan veya azalan bir fayda eğilimine sahip olduğunu varsaymaktadır. İdeal çözüm seti $A^{*}$, V matrisinin her bir sütunundaki en büyük değer, negatif ideal çözüm seti $A^{-}, \mathrm{V}$ matrisinin her bir sütunundaki en küçük değerler seçilerek oluşturulur. Her iki formülde de J fayda, J' ise kayıp değerini göstermektedir.

$$
\begin{array}{ll}
A^{*}=\left\{\left(\max _{i} v_{i j} \mid j \in J\right),\left(\min _{i} v_{i j} \mid j \in J^{\prime}\right\},\right. & A^{*}=\left\{v_{1}^{*}, v_{2}^{*}, \ldots, v_{n}^{*}\right\} \\
A^{-}=\left\{\left(\min _{i} v_{i j} \mid j \in J\right),\left(\max _{i} v_{i j} \mid j \in J^{\prime}\right\},\right. & A^{-}=\left\{v_{1}^{-}, v_{2}^{-}, \ldots, v_{n}^{-}\right\}
\end{array}
$$

TOPSIS yönteminde her bir karar noktasına ilişkin değerlendirme kriteri değerinin ideal ve negatif ideal çözüm setinden sapmalarının bulunabilmesi için Euclidian uzaklık yaklaşımından yararlanılmaktadır. Buradan elde edilen karar noktalarına ilişkin sapma değerleri ise İdeal Ayırım $\left(S_{i}^{*}\right)$ ve Negatif İdeal Ayırım $\left(S_{i}^{-}\right)$ölçüsü olarak adlandırılmaktadır.

$$
\begin{aligned}
& S_{i}^{*}=\sqrt{\sum_{j=1}^{n}\left(v_{i j}-v_{j}^{*}\right)^{2}} \\
& S_{i}^{-}=\sqrt{\sum_{j=1}^{n}\left(v_{i j}-v_{j}^{-}\right)^{2}}
\end{aligned}
$$

Her bir karar noktasının ideal çözüme göreli yakınlığının $\left(C_{i}^{*}\right)$ hesaplanmasında ideal ve negatif ideal ayırım ölçülerinden yararlanılır. Burada kullanılan ölçüt, negatif ideal ayırım ölçüsünün toplam ayırım ölçüsü içindeki payıdır. Bu yakınlık aşağıdaki formüller hesaplanır.

$$
C_{i}^{*}=\frac{S_{i}^{-}}{S_{i}^{-}+S_{i}^{*}}
$$

Burada bulunan $C_{i}^{*}$ değeri 0 ile 1 arasında bir değer alır. 0 olması ilgili karar noktasının negatif ideal çözüme, 1 olması ideal çözüme yakınlığını gösterir.

TOPSIS yöntemi ELECTRE yöntemine üstünlüğü her bir alternatifin kendi değerini almasıdır. Bu nedenle, alternatifler arasındaki farklılıklar ve kriterlerin birbirlerinden ne kadar farklı oldukları konusunda iyi bir görüş elde edilebilmektedir. Kolay uygulanabilir ve grafiksel olarak kolay görülebilir yöntemdir (Opricovic ve Tizeng, 2004).

\section{Uygulama}

Birçok iş alanına sahip bir bölüm bitirmiş mezunların çoğu hangi alana yönelecekleri ve hangi sektörü seçecekleri konusunda kararsız kalmaktadırlar. Seçenek fazla olunca kişiler kendi kriterlerine göre önlerine çıkan alternatiflerden en iyisini seçmeye çalışırlar. Bu seçim hem kendi kariyeri için hem de çalıştıkları yer için önemli bir karardır. Çalışmada önceki bölümlerinde anlatılan teorik bilgilerden yola çıkarak istatistik bölümünden mezun olmuş bir kişi için uygun iş alternatifi seçimi gerçekleştirilmiştir. Böylelikle kişinin kariyer planlaması oluşturulmuştur. Kişinin karşısında dört farklı alternatif vardır. Bunlar, "Bankada Uzman Yardımcısı" pozisyonu, "Üniversitede Araştırma Görevlisi" pozisyonu , "Belediyede İstatistikçi” pozisyonu ve "Özel Şirkette İstatistikçi” pozisyonudur. Kişi bu dört farklı iş için gerekli şartları sağlayacaktır fakat hangisini seçeceğine karar verirken zorlanmaktadır. Bu karar problemi AHP, ELECTRE I ve TOPSIS yöntemleriyle ayrı ayrı çözülmüş ve sonuçlar karşılaştırılmıştır. Böylelikle kişi için nihai karara ulaşılmıştır. 
Kariyer seçim kriterlerinin belirlenmesi için karar verici dahil olmak üzere istatistik bölümünden yeni mezun olan 50 kişiye araştırma amacı yüz yüze anlatılarak anket çalışması yapılmıştır. Verilen cevaplar düzenlenerek seçimdeki kriterler belirlenmiştir. Kriter belirlemek için karar vericinin yanı sıra diğer kişilerinde fikirlerinin alınmasının sebebi karar verici için önemli olan fakat o an aklına gelmeyen kriterlerinde göz ardı edilmemesidir. Bu dört iş alternatifinin kriter bazında değerlendirilmesi için kișinin karar vereceği kurumlarda aynı pozisyonda en az iki yıl çalışan personellerle görüşülerek, hem AHP yönteminde kriter bazda alternatiflerin karşılaştırılması için hem de ELECTRE I ve TOPSIS yönteminin uygulaması için personellerden sözel kriterlere 10 üzerinden puan verilmesi istenmiştir. Kriter bazında iş alternatifleri, deneyimli personellerin verdiği puanlamalara bakılarak, daha önce AHP alanında birçok çalışma yapmış bir uzman ile birlikte karşılaştırılmıştır. İstatistik bölümünden yeni mezun olan 50 kişiye (karar verici dahil) anket çalışması yapılmış katılımcıların tamamının ankette verilen kriterleri işaretlediği görülmüştür. Diğer seçeneğine yazılan şehir ve aileye yakınlık kriterleri, bu iş alternatifinin karar vericinin ailesiyle birlikte ikamet ettiği şehirde olması sebebiyle uygulamaya dahil edilmemiştir. Anket çalışması sonucunda iş seçimindeki kriterler aşağıdaki gibi belirlenmiştir.

Ekonomik Kazanç: İşverenin çalıştırdığı kişilere hizmet karşılığında her ay verdikleri net ücreti ifade etmektedir. Kişilerin iş hayatına atılmalarının ve hayatlarına devam etmelerinin temel nedeni, yaşamlarını istedikleri gibi devam ettirebilmek amacıyla para kazanmaktır.

Yükselme İmkanı: Hizmet süresinin artmasıyla veya işyerinde belirlenen şartların sağlanmasıyla birlikte gerçekleşen kademe değişiklikleridir.

Özlük Haklar: Kişilerin çalışmaya başladığı kadro veya pozisyonun getirdiği, kanunların öngördüğü şartlara bağlı olan tüm haklardır. Grev hakkı ve istifa hakkı bu haklara örnek gösterilebilir. Özlük haklarının iyi olması da kişiler için önemli bir kriterdir.

Çalışma Temposu: Çalışma yoğunluğunu ifade etmektedir. Mesai saatleri içindeki yoğunluğun getirdiği yorgunluğu göz önüne alarak iş seçmede bu kriteri de önemli görmüşlerdir.

Mesai Saatleri: Günlük iş başlangıç ve paydos saatlerini ifade etmektedirler. Bazı işyerlerinde paydos saati gelmesine rağmen işler uzamakta ve mesai saati artmaktadır. Bu durumları göz önünde bulundurarak kişilerin iş seçerken göz önünde aldığı kriterlerden biri olmaktadır.

Sosyal Hayat: Kişiler, çalışmaya başladıktan sonra iş koşullarına bağlı olarak zamanlarının çoğunu işte veya iş ile ilgili durumlarla geçirme sebebiyle eskisi gibi sosyal olamamaktadırlar. Dolayısıyla sosyal hayat kriteri, iş seçmede önemli bir kriter olarak karşımıza çıkmaktadır.

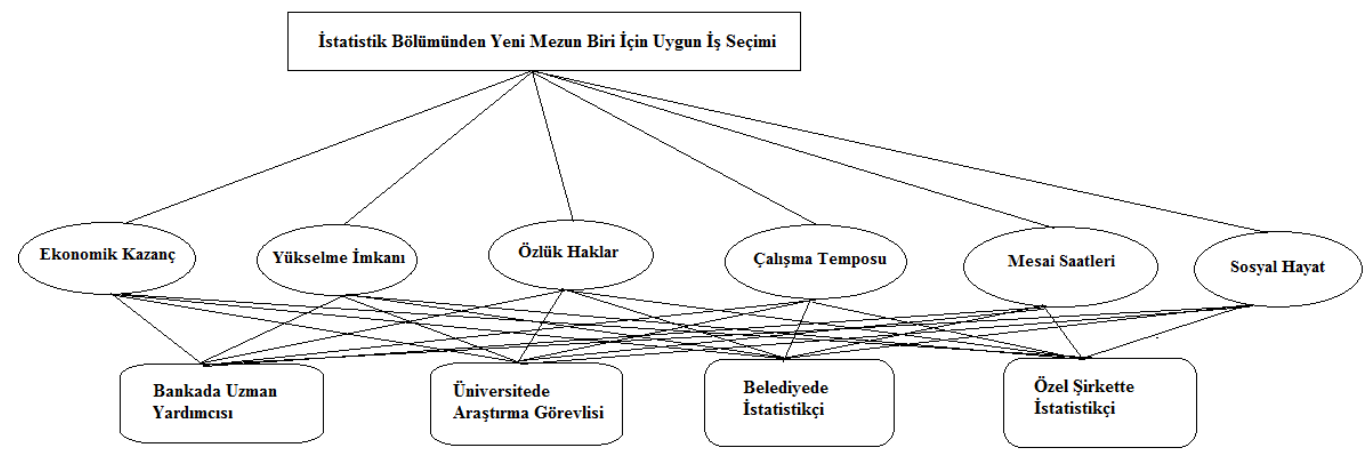

Şekil 6.1. Kariyer Planlaması Probleminin Hiyerarşik Yapısı

Anket yapılan personeller için en az iki yıl çalışma şartının konmasının sebebi değerlendirmelerin daha gerçekçi ve tutarlı olması içindir. Her kurum içindeki personellerin görüş birliğine vardığı puanlar aşağıdaki tabloda verilmiştir. 
Tablo 6.1. Kriterlerin Değerleri

\begin{tabular}{|l|c|c|c|c|c|c|}
\hline & $\begin{array}{l}\text { Ekonomik } \\
\text { Kazanç }\end{array}$ & $\begin{array}{l}\text { Yükselme } \\
\text { İmkanı }\end{array}$ & $\begin{array}{l}\text { Özlük } \\
\text { Haklar }\end{array}$ & $\begin{array}{l}\text { Çalş̧ma } \\
\text { Temposu }\end{array}$ & $\begin{array}{l}\text { Mesai } \\
\text { Saatleri }\end{array}$ & $\begin{array}{l}\text { Sosyal } \\
\text { Hayat }\end{array}$ \\
\hline Bankada Uzman Yrd. & 2450 & 8 & 8 & 5 & 4 & 6 \\
\hline Üniversitede Ar.Gör. & 2000 & 7 & 7 & 3 & 6 & 3 \\
\hline Belediyede İstatistikçi & 2200 & 5 & 8 & 7 & 8 & 9 \\
\hline Özel Şirket İstatistikçi & 1550 & 6 & 4 & 5 & 4 & 7 \\
\hline
\end{tabular}

\subsection{AHP Uygulamast}

Uygulama için Expert Choice programı kullanılmıştır. Expert Choice, yatırım portföy analizi ve ortak karar destek sağlayıcı bir yazılımdır. Bu programla amacın, kriterlerin ve alternatiflerin tanımlanmasında, ilişkilendirilmesinde ve ikili karşılaştırmalarının yapılmasına olanak verilmektedir. Programa amaç, kriterler ve karar vericinin yaptığı kriterlerin ikili karşılaştırma matrisi aşağıdaki gibi girilmiştir.

Tablo 6.2. Kriterlerin İkili Karşılaştırma Matrisi

\begin{tabular}{|l|c|c|c|c|c|c|}
\hline & $\begin{array}{l}\text { Ekonomik } \\
\text { Kazanç }\end{array}$ & $\begin{array}{l}\text { Yükselme } \\
\text { İmkanı }\end{array}$ & $\begin{array}{l}\text { Özlük } \\
\text { Haklar }\end{array}$ & $\begin{array}{l}\text { Çalışma } \\
\text { Temposu }\end{array}$ & $\begin{array}{l}\text { Mesai } \\
\text { Saatleri }\end{array}$ & $\begin{array}{l}\text { Sosyal } \\
\text { Hayat }\end{array}$ \\
\hline Ekonomik K. & 1 & 4 & 2 & 5 & 7 & 3 \\
\hline Yükselme İ. & 0,25 & 1 & 0,33 & 3 & 8 & 3 \\
\hline Özlük Haklar & 0,5 & 3 & 1 & 4 & 6 & 3 \\
\hline Çalışma Tem. & 0,5 & 0,33 & 0,25 & 1 & 0,5 & 0,33 \\
\hline Mesai Saatleri & 0,14 & 0,125 & 0,17 & 2 & 1 & 0,5 \\
\hline Sosyal Hayat & 0,33 & 0,33 & 0,33 & 3 & 2 & 1 \\
\hline \multicolumn{7}{|c|}{ Tutarsızlık Oranı: 0,08 } \\
\hline
\end{tabular}

Burada tutarsızlık oranının 0,08 olduğu görülür. $\mathrm{Bu}$ oranın 0,10 'dan düşük olması da kriterlerin karşılaştırılmasında AHP yöntemine göre tutarlı davranıldığını ifade etmektedir. Tutarsızlık Oranı, Excel programında teoride anlatılan formüllerle hesaplanabilirken Expert Choice programında ikili karşılaştırma değerleri matrise girilirken otomatik olarak hesaplanmaktadır. Aşağıdaki tabloda program tarafindan hesaplanan kriterlerin göreli önem değerleri görülmektedir.

Tablo 6.3. Kriterlerin Göreli Önem Değerleri

\begin{tabular}{|c|c|}
\hline Ekonomik Kazanç & 0,375 \\
\hline Özlük Haklar & 0,264 \\
\hline Yükselme İmkanı & 0,176 \\
\hline Sosyal Hayat & 0,092 \\
\hline Mesai Saatleri & 0,047 \\
\hline Çalışma Temposu & 0,046 \\
\hline \multicolumn{2}{|c|}{ Tutarsılık Oranı: 0,08} \\
\hline
\end{tabular}

Tabloda görüldüğü gibi en önemli kriter 0,375 değeri ile Ekonomik Kazançtır. Bu kriteri 0,264 ile Özlük Hakları, 0,176 ile Yükselme İmkanı, 0,092 ile Sosyal Hayat, 0,047 ile Mesai Saatleri izlemiştir. En düşük önemli kriter ise 0,046 ile Çalışma Temposu kriteridir.

6.1.2. Kriter Bazında Alternatiflerin İkili Karşılaştırma Matrislerinin Oluşturulması

Kriter bazında iş alternatifleri, deneyimli personellerin verdiği puanlamalara bakılarak, daha önce AHP alanında birçok çalışma yapmış bir uzman ile birlikte karşılaştırılmıştır. Sonuçlar aşağıdaki gibidir. 
Tablo 6.4. Kriter Bazında Karşılaştırma Matrisleri Sonucu Önem Değerleri

\begin{tabular}{|l|c|c|c|c|c|}
\hline Kriterler/Alternatifler & $\begin{array}{l}\text { Bankada } \\
\text { Uzman Yard. }\end{array}$ & $\begin{array}{l}\text { Üniversitede } \\
\text { Araştırma Gör. }\end{array}$ & $\begin{array}{l}\text { Belediyede } \\
\text { İstatistikçi }\end{array}$ & $\begin{array}{l}\text { Özel Şirkette } \\
\text { İstatistikçi }\end{array}$ & $\begin{array}{l}\text { Tutarsızlık } \\
\text { Oranı }\end{array}$ \\
\hline Ekonomik Kazanç & 0,53 & 0,136 & 0,281 & 0,053 & 0,08 \\
\hline Yükselme İmkanı & 0,467 & 0,277 & 0,095 & 0,16 & 0,01 \\
\hline Özlük Haklar & 0,441 & 0,164 & 0,327 & 0,068 & 0,08 \\
\hline Çalışma Temposu & 0,21 & 0,065 & 0,568 & 0,157 & 0,04 \\
\hline Mesai Saatleri & 0,108 & 0,242 & 0,57 & 0,08 & 0,04 \\
\hline Sosyal Hayat & 0,175 & 0,044 & 0,547 & 0,234 & 0,08 \\
\hline
\end{tabular}

Her bir kriter karşılaştırılmasında tutarsızlık oranı değeri \%10'dan düşük olmuştur. Bu karşılaştırmada yeterince tutarlı davranıldığını ifade eder. Ekonomik Kazanç, Yükselme İmkanı ve Özlük Haklar Kriterleri göz önüne alındığında en önemli alternatif "Bankada Uzman Yardımcısı" olarak hesaplanmıştır. Çalışma Temposu, Mesai Saatleri ve Sosyal Hayat Kriterleri göz önüne alındığında ise en önemli alternatif Belediyede İstatistikçi olmak olmuştur.

Kriter bazında karşılaştırmalardan sonra alternatiflere ait sıralama bulunur. Program aracılığıyla birçok farklı şekilde alternatif sıralamalarına ulaşmak ve farklı karşılaştırmalar yapmak mümkündür. Bu sayede karar verici hangi kriterde sıralamanın nasıl olacağını kolaylıkla görebilmektedir. Tablo 6.10'da tüm kriterler gözönüne alındığındaki alternatiflere ait sıralama verilmiştir.

Tablo 6.5. AHP Yöntemiyle Alternatiflerin Siralaması

\begin{tabular}{|l|l|}
\hline Bankada Uzman Yardımcısı & 0,432 \\
\hline Belediyede İstatistikçi & 0,305 \\
\hline Üniversitede Araştırma Görevlisi & 0,165 \\
\hline Özel Şirkette İstatistikçi & 0,098 \\
\hline
\end{tabular}

Buna göre, istatistik bölümünden yeni mezun olan karar verici için en uygun iş 0,432 değeri ile "Bankada Uzman Yardımcısı" alternatifi olarak hesaplanmıştır. Ardından 0,305 değeri ile "Belediyede İstatistikçi”" alternatifi gelmektedir. 3.Sırada 0,165 değeri ile "Üniversitede Araștırma Görevlisi" alternatifi vardır. En düşük öncelik değerine sahip alternatif ise 0,098 ile “Özel Şirkette İstatistikçi”" olarak hesaplanmıştır.

Sonuç olarak, kişinin kriterlere verdiği önem derecelerine göre kendisi için nihai kararı "Bankada Uzman Yardımcısı" pozisyonu oluşturacaktır.

\subsection{ELECTRE Uygulamasl}

ELECTRE I uygulamasında, yöntemde bahsedilen formüller kullanılarak uygulama gerçekleştirilmiştir. Bütün işlemler MS Excel programından yararlanılarak yapılmıştır. Karar matrisinin satırlarında üstünlükleri sıralanmak istenen karar alternatifleri, sütunlarında ise karar vermede kullanılacak kriterler yer almaktadır. Burada AHP başlangıç matrisine ek olarak ayrıca ELECTRE yöntemi uygulaması için karar vericiye ankette kriterleri toplamı 100 olacak şekilde ağırlıklandırması istenmiştir. (Uygulamada toplam 1 olarak alınır fakat karar vericiye kolaylık olması açısından toplam puanın 100 olması istenmiştir.

Tablo 6.6. Karar Vericinin Puanları

\begin{tabular}{|c|c|c|}
\hline Ekonomik Kazanç & 30 & 0,3 \\
\hline Yükselme İmkanı & 22 & 0,22 \\
\hline Özlük Hakları & 24 & 0,24 \\
\hline Çalışma Temposu & 9 & 0,09 \\
\hline Mesai Saatleri & 5 & 0,05 \\
\hline Sosyal Hayat & 10 & 0,1 \\
\hline Toplam & 100 & 1 \\
\hline
\end{tabular}


A matrisi karar vericinin verdiği ağırlıklar ve personelin verdiği puanlar ile oluşturulan başlangı̧̣ matrisidir.

Tablo 6.7. Başlangıç Matrisi

\begin{tabular}{|l|c|c|c|c|c|c|}
\hline & $\begin{array}{l}\text { Ekonomik } \\
\text { Kazanç }\end{array}$ & $\begin{array}{l}\text { Yükselme } \\
\text { İmkanı }\end{array}$ & $\begin{array}{l}\text { Özlük } \\
\text { Haklar }\end{array}$ & $\begin{array}{l}\text { Çalşma } \\
\text { Temposu }\end{array}$ & $\begin{array}{l}\text { Mesai } \\
\text { Saatleri }\end{array}$ & $\begin{array}{l}\text { Sosyal } \\
\text { Hayat }\end{array}$ \\
\hline W=0,30 & W=0,22 & W=0,24 & W=0,09 & W=0,05 & W=0,10 \\
\hline Banka & 2450 & 8 & 8 & 5 & 4 & 6 \\
\hline Üniversite & 2000 & 7 & 7 & 3 & 6 & 3 \\
\hline Belediye & 2300 & 5 & 8 & 7 & 8 & 9 \\
\hline Özel & 1550 & 6 & 4 & 5 & 4 & 7 \\
\hline TOPLAM & 8200 & 26 & 27 & 20 & 22 & 25 \\
\hline
\end{tabular}

Yöntemde verilen formüller yardımıyla bulunan alternatif sıralaması aşağıdaki tabloda verilmiştir.

Tablo 6.8. Alternatiflerin Siralanmasi

\begin{tabular}{|l|r|r|l|}
\hline & \multicolumn{1}{|l|}{$\begin{array}{l}\text { C } \\
\text { Değeri }\end{array}$} & $\begin{array}{l}\text { D } \\
\text { Değeri }\end{array}$ & \\
\hline Banka & 1,84 & $-1,733$ & 1.SIRADA \\
\hline Belediye & 0,84 & $-1,394$ & 2.SIRADA \\
\hline Üniversite & $-0,84$ & 1,084 & 3.SIRADA \\
\hline Özel & $-1,84$ & 2,044 & 4.SIRADA \\
\hline
\end{tabular}

Tabloda görüldüğü gibi istatistik bölümünden yeni mezun olmuş ve verilen iş alternatiflerinin koşullarını sağlayabilecek kişi için en uygun alternatif "Bankada Uzman Yardımcısı" pozisyonudur. Bunu belediyede istatistikçi, üniversitede araştırma görevlisi ve özel bir şirkette istatistikçi pozisyonu izlemektedir.

\subsection{TOPSIS Uygulamasl}

TOPSIS uygulamasında, teoride bahsedilen formüller kullanılarak uygulama gerçekleștirilmiștir. Bütün işlemler MS Excel programında yapılmıştır. TOPSIS yönteminin karar matrisinin standartlaştırılması ve ağırlıklandırılması ELECTRE yönteminin aynısıdır. Dolayısıyla ağırlıklandırılmış standart karar matrisinden sonraki aşamadan devam edilecektir.

Tablo 6.9. Ağırlıklı Standart Karar Matrisi

\begin{tabular}{|l|c|c|c|c|c|c|}
\hline & $\begin{array}{c}\text { Ekonomik } \\
\text { Kazanç }\end{array}$ & $\begin{array}{c}\text { Yükselme } \\
\text { İmkanı }\end{array}$ & $\begin{array}{c}\text { Özlük } \\
\text { Haklar }\end{array}$ & $\begin{array}{c}\text { Çalışma } \\
\text { Temposu }\end{array}$ & $\begin{array}{c}\text { Mesai } \\
\text { Saatleri }\end{array}$ & $\begin{array}{c}\text { Sosyal } \\
\text { Hayat }\end{array}$ \\
\hline Ăgırlıklar & $\mathrm{W}=0,30$ & $\mathrm{~W}=0,22$ & $\mathrm{~W}=0,24$ & $\mathrm{~W}=0,09$ & $\mathrm{~W}=0,05$ & $\mathrm{~W}=0,10$ \\
\hline Banka & 0,1747 & 0,1334 & 0,1382 & 0,0432 & 0,0174 & 0,0453 \\
\hline Üniversite & 0,1426 & 0,1167 & 0,1209 & 0,0259 & 0,0261 & 0,0226 \\
\hline Belediye & 0,164 & 0,0833 & 0,1382 & 0,0606 & 0,0348 & 0,068 \\
\hline Özel Ş. & 0,1105 & 0,1001 & 0,069 & 0,0432 & 0,0174 & 0,0581 \\
\hline
\end{tabular}

Yöntemde verilen formüller yardımıyla bulunan alternatif sıralaması aşağıdaki tabloda verilmiştir.

Tablo.6.10. İdeal Çözüme Göre Yakınlık Değerleri

\begin{tabular}{|l|l|l|}
\hline Alternatifler & $\begin{array}{c}\text { İdeal Çözüme } \\
\text { Yakınlık } \\
\text { Değerleri }\end{array}$ & Sıralama \\
\hline Banka & 0,767655379 & 1. Sırada \\
\hline Belediye & 0,673983904 & 2.Sirada \\
\hline Üniversite & 0,500623472 & 3. Srrada \\
\hline Özel & 0,293008865 & 4.Sirada \\
\hline
\end{tabular}


Tabloda görüldüğü gibi "Bankada Uzman Yardımcısı" alternatifi birinci sıradadır. Bunu "Belediyede İstatistikçi”, "Üniversitede Araştırma Görevlisi” ve Özel Şirkette İstatistikçi” alternatifleri izlemektedir.

\subsection{Uygulama Sonuçlarının Karşılaştırılması}

Her üç yöntem de karar verici için en uygun alternatifi, "Bankada Uzman Yardımcısı" pozisyonu olarak belirlemiştir. Buna göre, kriterlere verdiği ağırlıklara göre karar verici için nihai kararı oluşturacak alternatif "Bankada Uzman Yardımcısı" pozisyonudur. Yöntem sonuçlarında ortaya çıkan alternatif sıralaması aynıdır. $\mathrm{Bu}$, yöntemler uygulanırken karar vericinin ve ilgili kişilerin sürece dahil edilmesiyle nitel kriterlerin kişi ve kişilerin gerçek düşüncelerini yansıttığını gerçeğe yakın olduğunu ve yöntemlerin birbirini desteklediğini göstermektedir. Ayrıca aynı sonucun çıkması, uygulamada görüldüğü gibi mikro ölçekte karar verme problemlerinde üç yöntemin de uygulanabileceğini göstermiştir. Yöntemlerden çıkan sonuçların sıralamasının bile aynı olması yöntemlerin birbirini desteklediğini gösterir.

Bilindiği gibi TOPSIS yöntemi ELECTRE yönteminin temelleri üzerine geliştirilmiştir. ELECTRE yönteminde, çıan nihai karar veya sıralama AHP yönteminde çıkan nihai karar veya sıralamadan farklı çıksaydı bunun nedeni olarak, ELECTRE yöntemindeki uyumluluk ve uyumsuzluk setleri belirlenirken uyumluluk tarafına eşit olan değerlerin de ekleniyor olması bu setlerin değerlerini etkilediğini, ortalama değerlerin eşik değer olarak kabul edilmesi ve uygulanması olduğu söylenebilir. Çünkü bu eşik değerleri keyfi değerlerdir ve değiştirilmesi durumunda sonuç da değişebilecektir. Ayrıca nitel kriterlere değer verilirken karar vericinin gerçeğe yakın değerler vermemesi de bunun sebeplerinden biri olabilir.

\section{Sonuç ve Öneriler}

AHP yöntemi gerçek hayatta birçok karar verme probleminin çözümünde kullanılan ve her alanda uygulaması yapılabilen çok kriterli karar verme yöntemidir. Uygulaması kolay ve anlaşılırdır. Yöntem, karar verme problemlerinin çözümünde hem nicel hem de nitel kriterlerin sürece dahil edilmesine imkan tanır. AHP aynı zamanda grup halinde karar verilmesi gereken durumlarda etkin olması ve kendi içinde tutarlılı̆ııın olması bakımından da önemlidir. Ayrıca AHP ile duyarlılık analizi yapma imkanı vardır. AHP duyarlılık analizi, belli bir kritere verilen önem değerinin arttırıldığında ya da azaltıldığında nihai kararın nasıl değişeceğini gösterir. Bu analiz, AHP yönteminin ELECTRE yöntemine karşı bir üstünlük olarak kabul edilir. AHP yönteminin uygulanmasında dikkat edilmesi gereken en önemli konu amacın, kriterlerin ve alternatiflerin konu hakkında bilgi sahibi olan kişiler tarafindan belirlenmesi ve ikili karşılaştırılmalar yapılırken tutarlı davranılmasıdır. AHP yöntemi sonucunda "Bankada Uzman Yardımcısı" pozisyonu en iyi alternatif olarak gösterilmiştir.

ELECTRE yöntemi kolay uygulanabilir, ikili eleme yöntemine dayanan ve sonuçta üstün olan alternatifleri bir çekirdek olarak gösterebilen bir yöntemdir. ELECTRE yöntemi sonucunda "Bankada Uzman Yardımcısı" pozisyonu en iyi alternatif olarak gösterilmiştir.

TOPSIS yöntemi ELECTRE yönteminin temeli üzerine geliştirilmiş bir yöntemdir. TOPSIS kolay uygulanabilir, kolay anlaşılabilir, ideal çözüme en yakın negatif ideal çözüme en uzak alternatifi en iyi alternatif olarak seçen, grafiksel olarak kolay görülebilir bir yöntemdir. TOPSIS sonucunda da "Bankada Uzman Yardımcısı" pozisyonu en iyi alternatif olarak gösterilmiştir.

Yöntemlerin karar verme mantığı genelde ortak olsa da, sonuca ulaşmada işlem akışı, karar verici sayıları ve sıralamadaki küçük farkları yakalama becerileri ile tutarlılık testlerine imkân vermesi gibi özellikleriyle değişim göstermektedirler.

Uygulama sonucunda açıkça görülüyor ki AHP' nin ELECTRE ve TOPSIS yöntemine olan bir üstünlüğü duyarlılık analizinin yapılabilmesi ve her aşamada tutarsızlığın kontrol edilebilmesidir. Böylelikle karar verme süreci tamamlandıktan sonra bile karar verici yargılarında yaptığı değişikliklerin sonucu nasıl etkilediğini tüm işlemleri baştan yapmadan kolayca görebilmektedir.

AHP, duyarlılık analizi ile ELECTRE ve TOPSIS uygulamasını desteklemiştir. Bu üç yöntemin aynı sıralama ile aynı sonucu vermesi de kararın güvenilirliğini arttırmıştır. Böylelikle yöntemlerin birlikte kullanılması daha etkin ve güvenilir bir karara ulaşılmasını sağlamıştır.

Üç yönteminde ürettiği sonuçlar itibariyle farkı bakış açıları geliştirmesi açısından, maliyet ve zaman problemi de yaratmamasından ve bütün süreci bir sistematik içerisine sokmasından dolayı üçünü birlikte uygulayarak sonuçları ortaya koymak daha faydalı olacaktır.

Bu çalı̧̧ada, AHP, ELECTRE ve TOPSIS yöntemlerini ele alınarak, istatistik bölümünden yeni mezun olan kişi için kariyer planlamasındaki karar verme sürecinde yardımcı olunmaya çalışılmıştır. Yapılan AHP, ELECTRE ve TOPSIS analizleri sonucunda, yöntemler aynı sonucu vermiş ve istatistik bölümünden yeni mezun kişi için en uygun iş alternatifi olarak "Bankada Uzman Yardımcısı" pozisyonu

56 | P a g e 
bulunmuştur. Diğer alternatifler "Belediyede İstatistikçi ” , “Üniversitede Araştırma Görevlisi” ve “Özel Şirkette İstatistikçi”" olarak sıralanmıştır. Bu sıralama sonucunda kişi için nihai karar kriterlere verdiği öneme göre kendine en uygun olan alternatif olan "Bankada Uzman Yardımcısı" pozisyonudur.

$\mathrm{Bu}$ çalışma, meslek seçimi, kariyer planlaması ve farklı bölümler için iş alternatifleri arasından en uygununu seçme problemlerinin yanı sıra AHP, ELECTRE ve TOPSIS yöntemleri ile ilgilenen kişilere kaynak olabilir.

Çalışmada sonuçların mantıklı çıkması ve yöntemin uygulama kolaylığı bu alanda benzer çalışmalar için öncelik ve zemin oluşturacaktır.

\section{Bilgilendirme}

Bu çalışma Duygu Cengiz Usta’nın Yüksek Lisans tezinden üretilmiştir.

\section{Kaynakça}

ALP, S., \& Engin, T., (2011). "Trafik Kazalarının Nedenleri ve Sonuçları Arasındaki İlişkinin TOPSIS ve AHP Yöntemleri Kullanılarak Analizi ve Değerlendirilmesi”, İstanbul Ticaret Üniversitesi Fen Bilimleri Dergisi, Cilt.10, Sayı.19: 65-87.

AN, S-H, Kim, G-H., \& Kang, K-I., (2007). “A Case-Based Reasoning Cost Estimating Model Using Experience by Analytic Hierarchy Process”, Building and Environment, Vol 42: 2573-2579.

DAĞDEVİREN, M., \& Eren, T., (2001). "Tedarikçi Firma Seçiminde Analitik Hiyerarşi Prosesi ve 0-1 Hedef Programlama Yöntemlerinin Kullanılması”, Gazi Üniversitesi Mühendislik Mimarlık Fakültesi Dergisi, Cilt.16, Say1.2: 41-52.

DAĞDEVIREN, M., Akay, D., \& Kurt, M., (2004). “İş Değerlendirme Sürecinde Analitik Hiyerarşi Prosesi ve Uygulaması”, Gazi Üniversitesi Mühendislik Mimarlık Fakültesi Dergisi, Cilt.19, Sayı.2: 131-138.

DAŞDEMİ, İ., \& Güngör, E., (2002). "Çok Boyutlu Karar Verme Metotları ve Ormancılıkta Uygulama Alanları”, ZKÜ Bartın Orman Fakültesi Dergisi, Cilt.4, Sayı.4: 1-19.

DUMANOĞLU, S., (2010). "IMMKB'de İşlem Gören Çimento Şirketlerinin Mali Performansının TOPSIS Yöntemi ile Değerlendirilmesi”, Marmara Üniversitesi İ.İ.B.F Dergisi, Cilt.19, Sayı.2: 313-339.

ERSÖZ, F., \& Kabak, M., (2010). "Savunma Sanayi Uygulamalarında Çok Kriterli Karar Verme Yöntemlerinin Literatür Araştırması”, Savunma Bilimleri Dergisi, Cilt.9, Sayı.1: 97-125.

ERPOLAT, S., \& Cinemre, N., (2006). “ Analitik Hiyerarşi Yöntemiyle İş Sektörü Seçimi”, Öneri Dergisi Marmara Üniversitesi Cilt.7, Say1.25: 231-241.

JADIDI, O., Hong, T.S., Yusuff, R.M., \& Zulkifli, N., (2008). “TOPSIS and Fuzzy Multi-Objective Model Integration for Supplier Selection Problem", Journal of Achievements in Materials and Manufacturing Engineering, Vol.31, No.2: 764-765.

KURUÜZÜM, A., \& Atsan, N., (2001). “Analitik Hiyerarşi Yöntemi ve İşletmecilik Alanındaki Uygulamaları”, Akdeniz İ.İ.B.F Dergisi, Cilt.1, Sayı.1: 83-105.

OPRICOVIC, S., \& Tzeng, G-H., (2004). “Compromise Solution by MCDM Methods: A Comparative Analysis of Vikor and TOPSIS”, European Journal of Operational Research, Vol.156, No.2: 444-455.

RAMANATHEN, R., \& Ganesh, L.S., (1995). “Using AHP for Resource Allocation Problems”, Europan Journal of Operational Research, 80(2): 410-417.

ROY, B., (1991). "The Outranking Approach and the Foundation of ELECTRE Methods", Theory and Decision, Vol.31, No.1: 49-73.

SAATY, T.L., \& Vargas, L.G., (1987). "Uncertainty and Rank Order in the Analytic Hierarchy Process", European Journal of Operational Research, Vol.32: 107-117.

57 | P a g e

www.iiste.org 
SAATY, T.L., (1990). "How to Make a Decision: The Analytic Hierarchy Process", European Journal of Operational Research, Vol.48: 9-26.

SAATY, T.L., (1980). “The Analytic Hierarchy Process”, Mc-Graw Hill International Book Company, USA.

SONER, S., \& Önüt, S., (2006). "Multi-Criteria Supplier Selection: An ELECTRE-AHP Application”, Journal of Engineering and Natural Sciences, Vol.4: 110-120.

TRIANTAPHYLLOU, E., (2003). "Multi-Criteria Decision Making Methods: Acomperative Study", Kluwer Academic Publishers, Dordrecht. 3:13

TÜRKMEN ,S.Y., \& Çağıl, G., (2012). “IMKB'ye Kote Bilişim Sektörü Şirketlerinin Finansal Performanslarının TOPSIS Yöntemi ile Değerlendirilmesi”, Maliye Finans Yazıları, Cilt. 26, Sayı. 95: 59. 78.

YARALIOĞLU, K., (2001). "Performans Değerlendirmede Analitik Hiyerarși Prosesi”, Dokuz Eylül Üniversitesi İ.̇̇.B.F, Cilt.16, Say1.1: 129-142.

YOO, K.E., \& Choi, Y., (2006). “Analytic Hierarchy Process Approach for Identifying Relative Importance of Factors to Improve Passenger Security Checks at Airport", Journal of Air Transport Management, Vol 12: 135-142.

YURDAKUL, M., \& İç, T., (2003). “Türk Otomotiv Firmalarının Performans Ölçümü Analizine Yönelik TOPSIS Yöntemini Kullanan Bir Örnek Çalışma”, Gazi Üniversitesi Mühendislik Mimarlık Fakültesi Dergisi, Cilt.18, Sayı.1: 1-18.

YURDAKUL, M., (2002). “Measuring a Manufacturing System’s Performance Using Saaty's System Feedback Approach”, Integrated Manufacturing Systems, Vol.13, No.1: 25-34.

YÜCEL, M., \& Ulutaş, A., (2009). “Çok Kriterli Karar Yöntemlerinden ELECTRE Yöntemiyle Malatya'da Bir Kargo Firması İçin Yer Seçimi”, SÜ İ̈BF Sosyal ve Ekonomik Araştırmalar Dergisi, Cilt11, Sayı.17: 331 336

YÜREKLİ, H., (2008). “Taaruz Helikopter Seçiminde ELECTRE Yönteminin Kullanılması”, Doktora Tezi, İstanbul Üniversitesi Sosyal Bilimler Enstitüsü, İstanbul. 